УДК 339.9.012

Научная статья

DOI 10.18101/2306-630X-2020-1-61-70

\title{
CORONAVIRUS PANDEMIC (COVID-19) AND ITS AFTERMATH ON CONTEMPORARY WORLD AFFAIRS
}

\author{
(C) Bazar Sanjmyatav \\ Ph.D. (International Economics), \\ Professor of National University of Mongolia, \\ 8th khoroo, Baga toiruu 34, Ulaanbaatar 14191, Mongolia \\ bsanjmyatavv@gmail.com
}

\begin{abstract}
As the conception of security consolidates our prosperity to evolve on this planet that revolutionises our social norms and values from time-to-time, it also encounters threats and challenges that could potentially deliver a massive impact to the world. For instance, such security dilemmas would result in transforming the world order, international relations or even the lives of billions. This is the novel coronavirus pandemic of 2019 (COVID-19) that has changed the world for an indefinite period. Thus, it has forced us into a new phase, new norms and a new world. The article examines the impacts of the coronavirus outbreak on the political, economic and social world order through the lens of international relations.

Keywords: COVID-19; pandemic; world affairs; international security; social problem.
\end{abstract}

\section{Для цитирования}

Sanjmyatav B. Coronavirus pandemic (COVID-19) and its aftermath on contemporary world affairs // Евразийство и мир. 2019. № 2. С. 61-70.

\section{The Coronavirus Crisis}

The COVID-19 pandemic is a crisis like no other as it is proved to be more versatile and contagious. In fact, no other past diseases or pandemics had affected the world economy in such high magnitude as COVID-19. Notably, the UN Crisis Management Team under the leadership of Dr Michael Ryan, Executive Director of the WHO Health Emergencies Programme is working on effective ways to tackle this pandemic. In this way, the WHO will focus on the prioritising the health response whilst other Non-Governmental Organisations and other agencies can bring their respective expertise to bear on the wider social, economic and developmental implications of the coronavirus outbreak. Hence, COVID-19 could get contained promptly if the leading non-partisan institutions work to their respective strengths and expertise.

The coronavirus is "the most challenging crisis we have faced since the Second World War" according to the UN Secretary-General Antonio Guterres, and he amplified the fact that we need to take aggressive medical and economic efforts to thwart coronavirus [1]. Furthermore, the IMF Managing Director Kristalina Georgieva had noted that "the human costs of the coronavirus pandemic are already immeasurable and all countries need to work together to protect people and limit the economic damage" [2].

It is estimated that half of Europe will be affected the most as a result of this crisis, including economic and social impacts and China is expected to be hit by its second wave 
again. On the contrary, the actual crisis is likely to last for at least one to two years and the first signs of vaccine could be ready in 18 months. Therefore, it is recommended to prepare ourselves using every available resource we have today to combat this coronavirus outbreak while bracing ourselves for the long-term plans as well.

\section{Impacts of Coronavirus Crisis}

Eventually, the coronavirus storm will pass and humanity will thrive once again. However, we will be in a different environment. As of this, in this article, I will not solely discuss the spread of the coronavirus and the number of countermeasures taken by countries around the world, but I will also prioritise and focus more on the consequences of this outbreak and the forecast of international order.

As a researcher, I assume this coronavirus crisis will have major political, economic and social impacts on top of drastically impacting the public health sector. As a consequence, this crisis is expected to leave its legacy on world order, economic cooperation between states and social norms by impacting negatively. These impacts are described below.

\section{A) Political Impacts}

The international community is in a state of a global crisis and it is undeniably true that most world catastrophes in the past had upset the economic, political and strategic balance of power. Just think of it as a ripple effect since the conception of 'crisis' in the paradigm of realism creates security dilemmas over time and space to forge 'before' and 'after' phenomena. They often function as the accelerators of setting contemporary trends in world affairs in times of anarchy. Also, they precipitate the decline of certain actors whereas others strengthen their position. Therefore, we will have incompetent leadership on an international stage.

For instance, the UN Security Council could not agree on a resolution in regards to tacking the COVID-19 due to lack of political arrangements between the United States and China. This is significant but unprecedented reality, considering both states are regarded as superpowers and their inability to reach an agreement means this is an unprecedented reality. Notably, even during the Cold War, the US and the USSR had managed to agree to favour the search for a vaccine against polio, but 30 years later the world superpowers are now failing to reach mutual understanding. Sadly enough, the Trump administration labels the COVID-19 as a 'Chinese virus', accuses China to take responsibility and opted out from research contributions in the search for the vaccine. Rather than becoming an exemplary role model on the international state in times of crisis, the two superpowers' approach can be illustrated by 'The Game of Chicken' while the outcome is ideal for one actor to yield but both actors try to avoid it out of pride for not wanting to be interpreted as the chicken.

The situation contrasts singularly with what we had known in the 2000s with the implementation of the Global Plan against AIDS or the mobilisation against Ebola or at the time of the 2008 financial recession. In the above mentioned two cases of AIDS and Ebola, the voting in the UN Security Council was unanimous and this unanimity has fostered mobilisation around the world. Also in those two same cases, the US assumed the role of a global leader rather than criticiser. However, the current US administration has been cut off from such a task. 
In a contemporary setting, the economic tension that resulted from the global pandemic will continue for an indefinite period as a consequence of the US and China confrontation. Importantly, the former US Secretary of State, Henry Kissinger had said the leaders must prepare now to transition into a post-coronavirus world order. This transitional phase discussion rages numerous think-tanks around the world. The countries who most effectively responded to the coronavirus outbreak will gain recognition and will emerge as the leaders of the new world order.

Additionally, the Harvard international relations theorist Stephen Walt believes that coronavirus will accelerate the shift of power and influence from West to East, signifying countries such as South Korea and Singapore have shown the best response to COVID-19 and taken substantial counter measurements, not to mention China's effort to successfully contain the crisis in the aftermath of the initial outbreak. On the other hand, the initial state responses in Europe and the US in regards to the COVID-19 outbreak had been very sceptical and now they are paying the price, which has weakened their global powerhouse status through the lens of the balance of power spectrum [3].

B) Future of Neoliberalism

This pandemic will not mark the end of globalisation though, but it will question a certain number of its methods and ideological presuppositions including the famous neoliberal trilogy, which are opening of markets, decline of the state and privatisations. This questioning was already underway even before the start of the COVID-19 outbreak and it will continue to be a matter of discussion.

This coronavirus pandemic proves that no one is safe, not even the most powerful country in the world. As we have seen, no country is immune to COVID-19 and it has certainly affected all markets across the world. In this view, it also proves that world security, peace, global warming, raw material and energy resources cannot be solved by one actor or group of state actors alone. Hence, the states around the world have no choice but to cooperate closely together to overcome global disasters.

We can see with this pandemic that spontaneous demand for the state is increasing and that countries with high social protection are better equipped to face this pandemic than those who let their citizens face the reality alone.

Inversely, the COVID-19 pandemic will highlight the fact that globalisation increases the vulnerability of states who do not take the necessary precautions to ensure their security on a larger scale. Therefore, states should implement the idea of strategic autonomy in leading the fight against such pandemics.

In times of crisis though, the role of the state has grown significantly, and only the state has a role to play in saving the country from various difficult circumstances. When the 2008 global financial recession ended, the G20 summit announced that market economy regulation was already outdated and rather the transition to a state-regulated market economy would supersede. In the current context, when the coronavirus pandemic ends, the economic recovery will require a longer period and will need to be regulated by the state actors. In the above-mentioned condition, the role of the state is increasing even more than before in regulating the economy in the post-crisis era, and countries will be guided under the national strategy and common policy. 
Consequently, rehabilitating the strategic role of the state will be prioritised after the pandemic. It is considered that the main purpose of the state is to ensure the basic needs of the general population such as security, order and economic prosperity. The states are responsible for ensuring that people meet their basic needs.

C) National and World Wealth Distribution

There will be a significant economic loss everywhere around the world and the severity of this economic impact will depend on the duration of this pandemic as well as on the measures taken by state governments on an international level. For instance, China and the EU are likely to suffer the most from this COVID-19 pandemic and many economically developing countries are likely to spend a lot of time and resources in recovering from the economic consequences such as bankruptcies.

Following the coronavirus pandemic, China's global trade and investment will decline as global economic globalisation narrows, relocating the Global Value Chain and consumption in overall declines. However, the EU's case in the aftermath of the crisis, the union's internal integration will weaken and member states will tend to withdraw from the rights previous transferred to Brussels, which would increase both the unemployment and poverty rates. These factors will significantly affect in lowering the standard of living in Europe. On the other hand, the rising poverty, declining economic activity and global scarcity of monetary and investment will slow down the development of the third world countries and thus, could jeopardise their state stability.

During the coronavirus crisis, the Small and Medium Enterprises and farmers are likely to declare bankruptcy, forcing them to sell their properties and businesses for almost no value. In this case, the affluent will buy those and resell afterwards to make a profit out of them. Thus, the main conclusion can be drawn from the above that this pandemic event marks the second global distribution of wealth since the World War II, as the first distribution of wealth took place after the 2008 global monetary and financial recession. In other words, in the aftermath of this coronavirus crisis, the world order and the economic power will shift radically from the West to East into Asia. Therefore, Asia will become a major powerhouse and global driver of economic development.

D) Fading Human Rights

In times of crisis, it is easier to implement new counter-measures than evoking current ones. Numerous short-term emergency measures will become part of social norms and this is exactly the nature of the state of emergencies. In this sense, the measures taken by government agencies in efforts to administer and enforce their citizens into lockdowns will likely to remain in the aftermath of this coronavirus crisis. Lastly, the supply chains are now breaking apart due to the closure of industrial facilities and the confinement of workers and consumers are prevented from travelling or engaging in social activities. Therefore, these enforced countermeasures are a setback for human rights.

\section{Economic Impacts}

A) Declining Global Economy

The COVID-19 pandemic will diminish over time. However, its impact on the global economy as well as on society will be enormous and long-standing. For instance, the IMF Managing Director Kristalina Georgieva has noted in regards to the outlook for global financial growth that it will be negative for 2020 - a recession at least as bad 
as during the 2008 Global Financial Crisis or worse, but expected to recover in 2021. To fully recover from the economic setback, it is important to prioritise containment of COVID-19 and strengthen the health policies around the world even though the economic impact will be severe. Hence, the faster the outbreak stops, the quicker and stronger the recovery will be [4].

According to the World Economic Outlook from April 2020, the global economy in 2020 has fallen to negative 3 per cent, which is shown in figurel below.

\section{(real GDP growth, year-on-year percent change)}

1

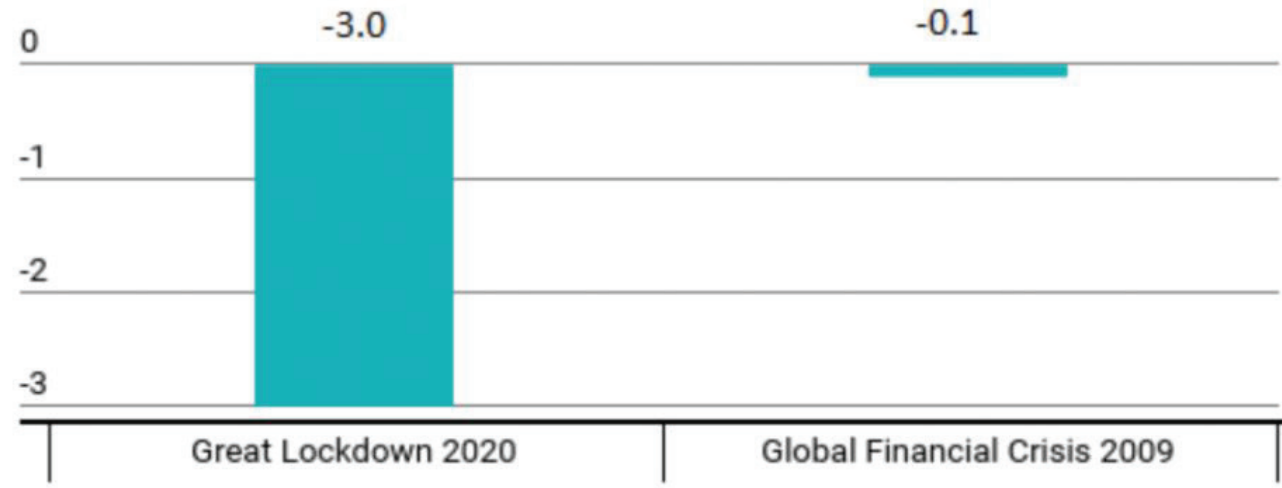

Source: IMF, World Economic Outlook.

Figure 1: World Economic Outlook 2020

The cumulative loss to the global GDP over 2020 and 2021 from the COVID-19 pandemic could be estimated at around 9 trillion dollars, which is far greater than the combined economies of Japan and Germany. This is truly a global crisis as no country is spared from the effects of COVID-19 pandemic, and countries whose economy solely rely on the tourism and hospitality industries are experiencing particularly large economic disruptions. Emerging markets and developing economies face additional challenges with unprecedented turnarounds in capital flows as global risk appetite wanes and currency pressures whilst coping with weaker health systems. Further, more limited fiscal space to provide support. Besides, several economies had entered this economic crisis in a vulnerable state with sluggish growth and high debt levels.

For this year, the growth in advanced economies is projected at negative 6.1 per cent. Emerging markets and developing economies with normal growth levels well above advanced economies are also projected to have negative growth rates of -1.0 per cent in 2020 and -2.2 per cent if you exclude China. The income per capita is projected to shrink for over 170 countries. Hence, both the advanced economies and developing economies are expected to partially recover starting from 2021. 
B) Change in Global Value Chains (GVC)

In the last decade, globalisation has increased with the establishment of numerous and extensive value chains to minimise production costs. The COVID-19 outbreak is disrupting the manufacturing and global value chains with negative implications for businesses, consumers and the global economy. The present value chains are more global and complex in comparison to the former value chains back in 2003 or in 2011.

The digitalisation of the economy has amplified this phenomenon in the development of telecommunications and collapse in the cost of transportation, which benefited numerous developing countries, particularly China and India. For instance, China has captured a large part of the world's textile production and consumer electronics, and India is the leading country in the pharmaceutical industry. Notably, in Wuhan, the ground-zero of the COVID-19 outbreak, more than 300 of the world's top 500 companies had set up their branches and operations. Such massive extensions of value chains naturally fed the idea of not requiring suppliers for stocks when they could become their own suppliers themselves. Eventually, when the crisis ends, the chains of value will stay in the game as their economic interest remains.

Given the contagious nature of COVID-19, the governments around the world had closed their borders and it has made GVC impossible to operate. As hundreds of millions are isolated under strict lockdowns, social distancing and self-isolation has jeopardised some of the economic policies around the world to some extent. For instance, the US' notorious 'America First' policy does not favour international cooperation as the US had enforced economic sanctions on countries such as Russia, Iran and DPRK apart from engaging in a trade war against China. As a consequence, most factories worldwide had closed their doors and the service sector is shut down.

According to Resilinc, the suppliers of the world's largest 1,000 companies own more than 120,00 facilities, including factories, warehouses and other operational centres in the COVID-19 quarantined areas in China, Italy and South Korea [5]. For instance, Apple collaborates with suppliers from 43 countries, all of which receive components from contract manufacturers in China. Ironically, China had already become the centre of GVC. China has become a global player in the global economy, which the country had successfully grown from 9 per cent of global manufacturing output in 2003 to more than 28 per cent as of 2020. China's success is due to the country's improved infrastructure in more advanced transportation networks in recent years [6].

In the context, there are two development trends that most countries practice in the framework of the world economy. First, countries aim to reduce their dependency on foreign investments and seek to expand their regional cooperation. Second, they seek to produce a surplus of strategic goods to circulate their economies. As a result of these two measures, GVC is expected to change due to increasing industrialisation policies in developing countries that are aimed to integrate regional economies into main industrial hubs. Hence, the trade barriers and taxation to international trade will increase and global demand will decline for an undetermined period.

It is important to diversify supply resources into the health sector. The extent of dependency on China for imported goods is enormous such as masks and personal protective equipment. Additionally, around $40 \%$ of antibiotics are imported from China in countries 
like Germany, Italy and France as China supplies $90 \%$ of the world's penicillin consumption [7]. To this end, the overdependency on one's export of essential products should be regulated and limited so that no country can be held responsible for a huge fraction of imports in times of emergency. One of the possible alternatives for the post-global world is the creation of special economic regions where there is a sufficient influx of mobility. In other words, the world market is transitioning from a single currency to regional markets with regional currencies.

C) Working from Home

Working from home during self-isolation or lockdowns is changing the conventional way of work through introducing virtual space where everyone can interact with each other over time and space with the help of the internet. Many enterprises and academic institutions have started practising this method by encouraging employees to work from home. Since the COVID-19 outbreak, the entire academic sector transitioned to online over social distancing rule. This unprecedented practice is approved and favoured by many employees, which allows them to be with their family during challenging times.

D) Degrading Immigration

The COVID-19 pandemic is radically impacting the social norms as it continuously weakens economic activity as the unemployment rate increases. Consequently, the sharp slowdown in the labour market tends to dramatically complicate the lives of immigrants living overseas. Moreover, anti-immigrant sentiment is growing by day among the Western countries, especially against Asian immigrants. According to the ILO in 2019, there are 130 million immigrants worldwide.

E) Outcomes

The coronavirus pandemic will affect not only the economic development but it also directly contributes to the level of unemployment, poverty rate, depreciation or appreciation of exchange rate and the overall quality standard of living. As unemployment has risen sharply, full or partial lockdown measures have affected almost 2.7 billion labour force, which represents 81 per cent of the world's total workforce. Amid this situation, business across various sectors are facing losses which threaten their existence, especially among smaller enterprises, forcing millions of workers to become vulnerable to income loss and layoffs.

The blow on the income-generating sector is hitting harsh on the unprotected workers and other more vulnerable groups in the informal economy. The ILO estimates that 1.25 billion workers who represent nearly 38 per cent of the global labour force are employed in sectors that are now facing a severe decline in output and facing a high risk of work displacement. These sectors include retail, hospitality and manufacturing industries ${ }^{1}$.

The COVID-19 pandemic is likely to cause the first major increase in global poverty since 1998. According to the World Bank statistics, the share of the world's population living on less than $\$ 1.90$ per day is projected to increase from 8.2 per cent in 2019 to 8.6 per cent in 2020. This roughly translates from 632 million people to 665 million people who could live under $\$ 1.90$ a day.

\footnotetext{
${ }^{1}$ International Labour Organisation. COVID-19 and the World of Work [Ebook] (2nd ed., pp. 111). [Электронный pecypc]. URL: https://www.ilo.org/wcmsp5/groups/public/—dgreports/— dcomm/documents/briefingnote/wcms_740877.pdf (дата обращения: 24.05.2020).
} 
As governments around the world effortlessly seek to revive their economies, they are printing large sums of monetary value to support financially difficult businesses. As a result, this may present a negative impact on the currency exchange rate. Notably, the Bretton Woods System estimated that more than $\$ 9$ trillion is being spent worldwide as a response to the declining financial markets. Furthermore, this will lead to depreciation of currency, which will in turn increase the cost of imported goods. Eventually, this results in a negative outcome on the standard of living of millions of people, especially in countries whose economy relies heavily on imports.

\section{Conclusion}

Based on the research above, the following conclusions can be drawn:

1. The COVID-19 pandemic has directly influenced the existing world order, contemporary international relations and the daily lives of every individual. This situation has opened a door to introduce a new period of a post-globalisation era, where the transitioning phase of world policy and the global economy from West to East has accelerated more than before.

2. The world we know before the COVID-19 outbreak is long gone and there is no looking back as this pandemic has completely changed the world.

3. The post-globalisation phase would leave the world in a deficit of leadership in the world. The present tension between the US and China under the sphere of a trade war would last longer than expected. In other words, the confrontation between the US and China can be translated into a new version of the 'Cold War'.

4. The state roles have grown significantly in times of crisis and only the state possesses the power and has the means to recover from difficult circumstances, not private enterprises. Rehabilitating the economy must be prioritised when the pandemic ends and states must give strategic importance to it.

5. The GVC will change and regional integration, as well as industrialisation policies will be the new trend in the developing economies. Over dependency on the world market and a single currency will fade and regional markets with local currencies will emerge.

6. It will be the second occurrence of redistributing global and national wealth since World War 2. When the COVID-19 pandemic ends, Asia will become the financial hub of the world.

7. The Virtual World will be a new paradigm for the labour market.

8. We will observe a sharp slowdown in the labour migration and the situation will worsen existing immigrants' conditions.

9. The countermeasures against COVID-19 has controlled the freedom of citizens to some extent during quarantines and isolations, and the strict government response to this pandemic is likely to remain in the aftermath of this outbreak. Thus, human rights will be affected to some degree around the world due to lack of freedom.

10. The outcomes of COVID-19 resulted in major political, economic and social turnovers that jeopardised the stability of many countries as this pandemic has increased the unemployment rate, poverty and reduced the standard of living for millions around the world. 
11. The COVID-19 may be a short term outbreak but it forced governments around the world to enforce long-term unified strategies and policies to contain the economic recession.

\section{References}

1. Epstein, K. UN secretary general called the coronavirus 'the most challenging crisis we have faced since the Second World War. Business Insider Australia [Электронный pecypc]. URL: https://www.businessinsider.com.au/coronavirus-biggest-global-threatsince-wwii-un-chief-2020-4?r=US\&IR=T (дата обращения: 24.05.2020).

2. Georgieva, K. The Great Lockdown: Worst Economic Downturn Since the Great Depression. IMF [Электронный ресурс]. URL: https://www.imf.org/en/News/ Articles/2020/03/23/pr2098-imf-managing-director-statement-following-a-g20-ministerialcall-on-the-coronavirus-emergency (дата обращения: 24.05.2020).

3. Wintour, P. Coronavirus: who will be winners and losers in new world order? The Guardian [Электронный ресурс]. URL: https:/www.theguardian.com/world/2020/ apr/11/coronavirus-who-will-be-winners-and-losers-in-new-world-order (дата обращения: 24.05.2020).

4. Georgieva, K. The Great Lockdown: Worst Economic Downturn Since the Great Depression. IMF [Электронный ресурc]. URL: https://www.imf.org/en/News/ Articles/2020/03/23/pr2098-imf-managing-director-statement-following-a-g20-ministerialcall-on-the-coronavirus-emergency (дата обращения: 24.05.2020).

5. Linton, T., \& Vakil, B. Coronavirus Is Proving We Need More Resilient Supply Chains. Harvard Business Review [Электронный ресурc]. URL: https://hbr.org/2020/03/ coronavirus-is-proving-that-we-need-more-resilient-supply-chains (дата обращения: 24.05.2020).

6. Betti, F., \& Hong, P. Coronavirus is disrupting global value chains. Here's how companies can respond. World Economic Forum [Электронный pecypc]. URL: https://www.weforum.org/agenda/2020/02/how-coronavirus-disrupts-global-value-chains/ (дата обращения: 24.05.2020).

7. Borrell, J. (2020). COVID-19: le monde d'après est déjà là. Ifri.org. [Электронный ресурc] URL: https://www.ifri.org/fr/publications/politique-etrangere/articles-depolitique-etrangere/covid-19-monde-dapres-deja (дата обращения: 24.05.2020). 


\title{
ПАНДЕМИЯ КОРОНАВИРУСА (COVID-19) И ЕЕ ВЛИЯНИЕ НА СОВРЕМЕННЫЕ МЕЖДУНАРОДНЫЕ ОТНОШЕНИЯ
}

\author{
(C) Базарын Санжмятав \\ доктор наук (мировая экономика), профессор, \\ Монгольский государственный университет \\ Монголия, 14191, г. Улан-Батор, Бага тойру 34, 8-й хороо \\ bsanjmyatavv@gmail.com
}

\begin{abstract}
Аннотаиия. Концепция безопасности наряду с укреплением процветания стран и народов сосредоточивает свое внимание на мерах противодействия угрозам и вызовам, с которыми периодически сталкивается мир. Основные вопросы безопасности связаны с изменением мирового порядка и системы международных отношений, способным отразиться на жизнях миллиардов людей. Ярким примером вопроса глобальной безопасности является пандемия коронавируса (COVID-19), изменившая мир на неопределенный срок и заставившая нас вступить в новую фазу развития, осваивать новые нормы существования. В данной статье рассматривается воздействие вспышки коронавируса на политические, экономические и социальные измерения международных отношений. Хотя первичной проблемой пандемии является угроза здоровью людей, по мере развития событий дают о себе знать и иные трудности. Санитарные ограничения, вводимые государствами, приводят к обострению таких социальных проблем, как безработица, бедность, преступность. Попытки правительств разрешить ситуацию путем увеличения денежной массы лишь подхлестывают инфляцию, что может привести к полной дезорганизации международной финансовой системы.

Ключевые слова: ковид-19; пандемия; мировая политика; мировая экономика; государство; международная безопасность; социальные проблемы.

Статья поступила в редакцию 22.08.20; одобрена после редактирования 07.09.20; принята к публикации 30.10.20.
\end{abstract}

